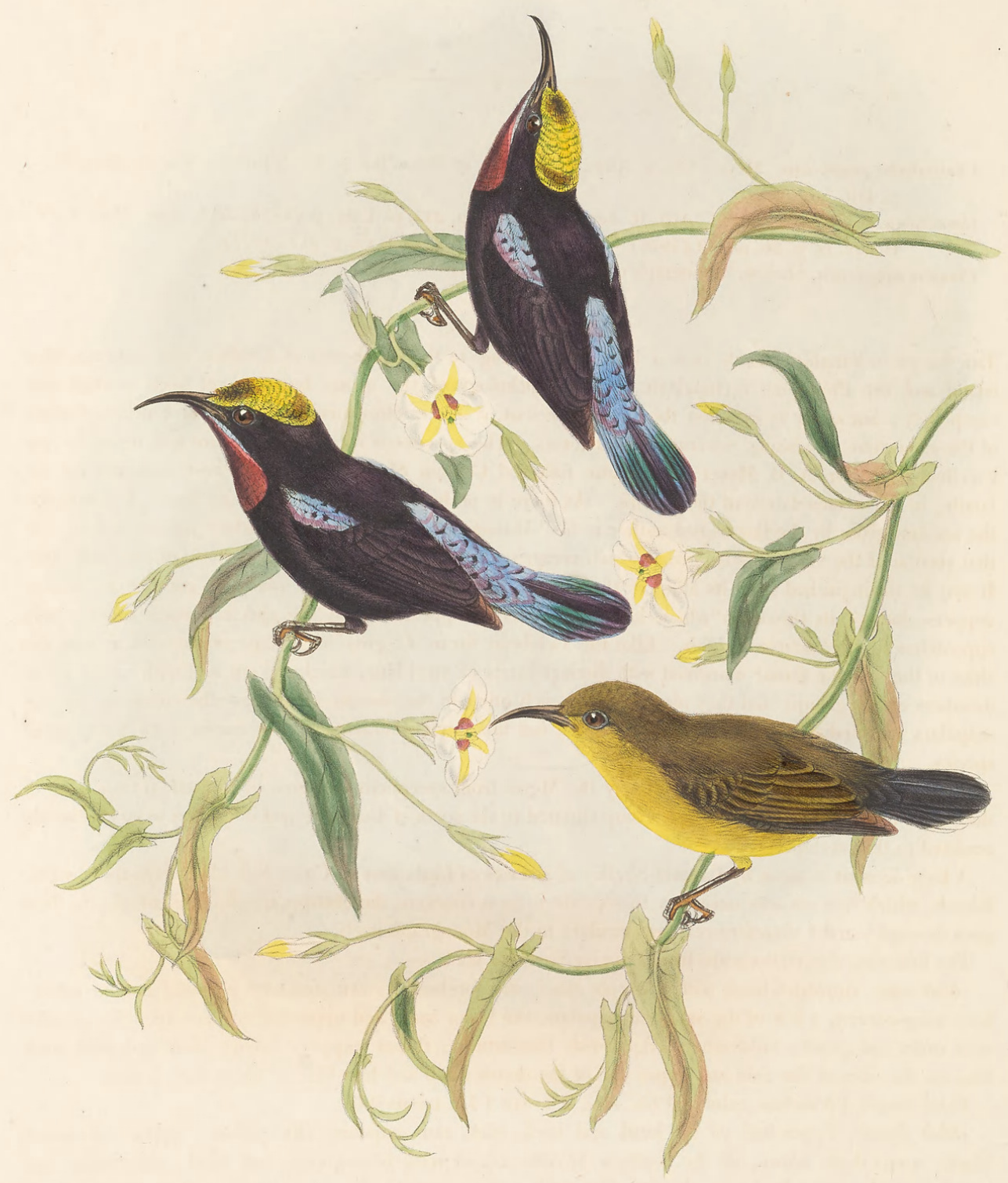

CINNYRIS SANGIRENSIS. 


\title{
CINNYRIS SANGIRENSIS.
}

\author{
Sanghir Black Sun-bird.
}

\author{
Chalcostetha sangirensis, Meyer, Sitz. k. Akad. Wissensch. in Wien, lxx. p. 124 (1874).-Sclater, Ibis, 1874, \\ p. 419. \\ Hermotimia sanghirensis, Salvad. Atti R. Accad. Torino, x. p. 233, pl. i. fig. 2 (1874).-Id. Ann. Mus. Civic \\ Genov. ix. p. 56, no. 10 (1876).-Id. Atti R. Accad. Torino, xii. p. 311 (1877). \\ Cinnyris sangirensis, Shelley, Monograph of the Cinnyridæ, part v. (1877).
}

The Sangir or Sanghir Islands are a little group lying to the north-east of Celebes, and between that island and the Philippine archipelago. The ornithology of the group has not yet been worked out completely; but as far as we know the facts at present, it is very closely related to that of Celebes, though at the same time possessing several peculiar forms. The specimens which I figure are lent to me by my excellent friend Dr. A. B. Meyer; and I have followed Captain Shelley, who is our best authority on the family, in the nomenclature of the species. As there is nothing known concerning its habits, I transcribe the account given by the last-named author in his 'Monograph : '- " This well-marked species belong's to that section of the 'Hermotimia' group which comprises species with the metallic portions of the back blue. It may be distinguished from its allies by the general brownish shade of its plumage, and by the bronzy copper-colour of its throat, in which latter character it appears to be the species which most nearly approaches to Chalcostetha insignis. Like the Celebean forms $C$. grayi and C.porphyrolcemus, it has the sides of the metallic throat margined with distinct bands of steel-blue, which are not met with in the other members of this group; and they also resemble each other in the absence of the metallic colouring on the scapulars and median series of the wing-coverts; but this latter character is not confined to these three species.

"The present bird was first described by Dr. Meyer from specimens collected by himself at Siao, one of the Sangir or Sanghir islands, a small group situated to the north of Celebes; and it appears to be exclusively confined to that archipelago."

A long account is given by Captain Shelley of a series of birds sent to Count Salvadori from the Sanghir Islands, which it is not now necessary to reproduce, as it concerns the changes of plumage which the bird goes through; and I therefore refer my readers to the Monograph itself.

The following descriptions are from Captain Shelley's book :-

Adult male. Brownish black with a purple gloss; the forehead, crown, and nape metallic golden green; least wing-coverts, a few of the smallest scapulars, the lower back, and upper tail-coverts steel-blue, shaded with violet and green; tail-feathers edged with lilac-bronze; throat coppery bronze, margined with steelblue on the sides of the chin and upper half of the throat; bill and legs black; irides dark brown.

Total length $4 \cdot 3$ inches, culmen $0 \cdot 65$, wing $2 \cdot 4$, tail $1 \cdot 75$, tarsus $0 \cdot 6$.

Adult female. Upper half of the head and neck, back, and scapulars olive-yellow; upper tail-coverts black; wings dark brown, all the feathers broadly edged with olive-green; tail black, with white tips, broadest on the outer feathers; cheeks yellower than the crown; underparts sulphur-yellow, slightly tinted with olive on the sides of the breast, the under tail-coverts very pale yellow; under surface of the wings brown, with the inner margins of the quills and the coverts white, the latter shaded with yellow; bill, legs, and irides dark brown.

Total length 4 inches, culmen $0 \cdot 6$, wing $2 \cdot 05$, tail $1 \cdot 4$, tarsus $0 \cdot 6$.

The Plate represents two males and a female, of the natural size, for the loan of which I am indebted to Dr. Meyer. 


\section{$2 \mathrm{BHL}$ Biodiversity Heritage Library}

Gould, John and Sharpe, Richard Bowdler. 1878. "Cinnyris sangirensis, Sanghir Black Sun-bird [PI. 32]." The birds of New Guinea and the adjacent Papuan islands : including many new species recently discovered in Australia 3(VIII), -. https://doi.org/10.5962/p.322745.

View This Item Online: https://www.biodiversitylibrary.org/item/229963

DOI: https://doi.org/10.5962/p.322745

Permalink: https://www.biodiversitylibrary.org/partpdf/322745

\section{Holding Institution}

Smithsonian Libraries

\section{Sponsored by}

Biodiversity Heritage Library

\section{Copyright \& Reuse}

Copyright Status: Public domain. The BHL considers that this work is no longer under copyright protection.

This document was created from content at the Biodiversity Heritage Library, the world's largest open access digital library for biodiversity literature and archives. Visit BHL at https://www.biodiversitylibrary.org. 